\title{
Performance of two-chambered Microbial Fuel Cell (MFC) at different pH anode microenvironment using Palm Oil Mill Effluent (POME) as substrate
}

\author{
Aina Mardhiyah Jalilluddin ${ }^{1, a}$, Tay Chia-Chay ${ }^{2, b}$ Suhaimi Abdul-Talib ${ }^{3, c}$ \\ ${ }^{1,3}$ Faculty of Civil Engineering, Universiti Teknologi MARA, Shah Alam, Selangor, MALAYSIA \\ ${ }^{2}$ Faculty of Applied Sciences, Universiti Teknologi MARA, Arau, Perlis, MALAYSIA \\ ${ }^{1,3}$ Bioremediation Research Center (myBioREC), Institute for Infrastructure and Sustainable \\ Management (IIESM) \\ aainamardhiyah_amj1726@yahoo.com; btaychiay@gmail.com; ‘ecsuhaimi@salam.uitm.edu.my
}

Keywords: electricity generation; MFC; POME; pH; wastewater treatment

\begin{abstract}
Microbial fuel cell (MFC) represents a new method for producing electricity from the oxidation of organic matter. In addition, MFC offers an effective wastewater treatment. The feasibility of using POME wastewater as a substrate was investigated through a two-chambered MFC operated in batch mode for 12 days. The performance of MFC was evaluated under three different anode $\mathrm{pH}$ microenvironments of acidic $(\mathrm{pH} 4)$, neutral ( $\mathrm{pH} 7)$ and alkaline (pH 8). Results of experiments indicated that the MFC reactor was able to generate electricity and treat POME wastewater that acted as substrate for MFC. The performance of MFC was found to be dependent on the anode $\mathrm{pH}$ microenvironments. Higher power density was observed at neutral condition compared to acidic and alkaline conditions. Furthermore, significant reductions in chemical oxygen demand (COD) in anode chambers were found due to the changes of $\mathrm{pH}$ in anode microenvironment. This indicated that effective wastewater treatment of POME in MFC batch experiments. In conclusion, MFC provides an alternative, sustainability and effective method to generate electricity and effectively treat wastewater.
\end{abstract}

\section{Introduction}

Microbial fuel cell (MFC) is a biochemical reactor which has the ability to generate electricity and treat wastewater simultaneously. MFC generates electricity from the redox reaction with the aid of a catalytic reaction of microorganisms [1].

The catalytic reaction is initiated by the metabolic activity from the oxidation of organic matter by microorganisms in the anode chamber [2] This reaction generates electrons $\left(\mathrm{e}^{-}\right)$and proton $\left(\mathrm{H}^{+}\right)$ions. Electrons travel to the cathode chamber through an external circuit under an external resistance while proton ions diffuse to the cathode chamber through cation exchange membrane (CEM). At the cathode chamber, electrons reduce oxygen which acts as the electron acceptor to produce water. The process in the MFC is advantageous as it does not require the thermodynamic conversion step $[3,4]$. In addition, the biological process offers an economical method for both electricity generation and wastewater treatment.

MFC is classified as an alternative sustainable technology as it adopts the 'Waste to Wealth' concept where this technology uses biomass waste to act as a carbon source to fuel the cell. Patil et al. [5] have reviewed on variety of wastewater that has been used in MFC. To make MFC competitive with other technologies, agriculture and industrial wastewater are being considered to be the most suitable candidate as it is a cost free waste and sustainable resource [6]. Renewable energy generated by MFC, which uses different types of wastewater as carbon source, is relatively new in Malaysia.

Palm oil is an important economic product in Southeast Asia as well as in Malaysia. The palm oil mill is the biggest sector in manufacturing sector in Malaysia, thus establishing Malaysia as the world largest producer of palm oil. In 2008, it accounted for approximately $47 \%$ of world palm oil production and $54 \%$ of world exports [7,8]. The palm oil sector produces abundant wastewater known as Palm Oil Mill effluent (POME). POME is a viscous brown liquid containing high chemical oxygen demand (COD) with fine suspended solid (SS) [9]. POME must be treated to 
meet discharge regulations. Currently, POME is no longer seen as a waste, but instead a valuable energy source through MFC approach of treating wastewater organic matter and thus generates useful amount of renewable energy.

Generally, in a two-chambered MFC reactor, wastewater with high organic matter is placed in the anode chamber. The typical catalytic reaction is initiated by the bacteria in the anode chamber. The anode $\mathrm{pH}$ microenvironment is an important factor as bacteria activities depend on the $\mathrm{pH}$ conditions. Therefore, anode $\mathrm{pH}$ microenvironment is influenced by the bacteria activities and affected the $\mathrm{e}^{-}$and $\mathrm{H}^{+}$generation mechanism.

This paper focuses on electricity generation and wastewater treatment using a twochambered MFC utilizing POME wastewater as substrate with different anode microenvironments. These investigations not only lead to MFC approach for alternative renewable energy and wastewater treatment but also contribute to the sustainable practice and waste to wealth concept.

\section{Methods}

\subsection{Laboratory scale Microbial Fuel Cell (MFC) construction}

Three identical two-chambered MFC reactors were setup in this study. The MFC reactors were composed of two $500 \mathrm{ml}$ volume conical flask using salt bridge as a separator or act as a CEM. Salt bridges of $15 \mathrm{~cm}$ length and internal diameter of $0.8 \mathrm{~cm}$ were prepared using a mixture of $\mathrm{KCl}$ (Merck, Germany) and agar (Merck, Germany) in ratio of 1:1. The stoppers were equipped for sampling ports, wire input, salt bridge, and gas inlet and gas outlet. The electrodes used were carbon rod with projected area of $11.46 \mathrm{~cm}^{2}$. Prior to use, electrodes were soaked overnight in deionized water to remove organic contamination on the electrode surface. Electrodes were connected with copper wire through the resistance $3.3 \mathrm{k} \Omega$. Copper wire was sealed with rapid epoxy sealant to prevent reactions between copper wire and wastewater sample which might lead to corrosion. A multimeter (Fluke 289 True RMS Multimeter, Fluke Corporation, USA) was used in the setup to measure the produced voltage.

\subsection{Wastewater composition}

POME samples were collected from the Bukit Kerayong palm oil mill in Selangor, Malaysia. POME was used as a substrate for electricity generation in the anode chamber of the fuel cell. The average characteristics of POME wastewater samples used were $\mathrm{pH} 4.59$, conductivity $9.39 \mu \mathrm{S} / \mathrm{cm}$, suspended solid (SS) $87566 \mathrm{mg} / \mathrm{L}$ and chemical oxygen demand (COD) $98000 \mathrm{mg} / \mathrm{L}$. POME is considered as complex substrate in nature due to its composite nature and highbiodegradability. (BOD/COD 0.5).

Domestic wastewater (DWW) samples were collected from a local Sewage Treatment Plant in Universiti Teknologi MARA, Selangor, Malaysia. DWW was used as a biocatholyte which also acts as a cathode electrolyte in the cathode chamber of the fuel cell. The characteristics of DWW were $\mathrm{pH}$ 6.78, conductivity $246.86 \mu \mathrm{S} / \mathrm{cm}$, SS $98.87 \mathrm{mg} / \mathrm{L}$ and COD $264 \mathrm{mg} / \mathrm{L}$.

\subsection{Microbial Fuel Cell (MFC) operation}

Each assembled MFC reactor setup in Section 2.1 was filled with $500 \mathrm{ml}$ of aerated domestic wastewater (DWW) as biocatholyte that acts as a cathode electrolyte in all experiments. Air was supplied in the cathode chamber to promote aerobic condition.

On the other hand, the anode chamber was filled with $500 \mathrm{ml}$ of diluted POME at different $\mathrm{pH}$ as substrate. Anode $\mathrm{pH}$ of POME was adjusted to $\mathrm{pH} 4, \mathrm{pH} 7$ and $\mathrm{pH} 8$ respectively. The $\mathrm{pH}$ adjustments were conducted by using weak acid or base solutions to the design anode $\mathrm{pH}$ values. At the anode chamber, nitrogen $\left(\mathrm{N}_{2}\right)$ gas was purged within the POME sample for at least ten minutes to ensure the anode chamber was free from oxygen and hence created an anaerobic condition. Finally, adhesion promoter seal was applied at anode chamber to ensure the anaerobic condition.

Experimenst were operated at regular room temperature $\left(28 \pm 2^{\circ} \mathrm{C}\right)$ in a batch mode as suggested by $\mathrm{Du}$ et al. [10]. The amount of voltage produced during the experimental work was measured using a digital multimeter for each assembled MFC reactor. Data was recorded hourly for 
12 days. Experiments were carried out at different anode $\mathrm{pH}$ to evaluate the effects of $\mathrm{pH}$ on the electricity generation and wastewater treatment.

\subsection{Electrochemical analyses and calculations}

The performances of MFC were studied in terms of electricity generation at different anode $\mathrm{pH}$ microenvironments of $\mathrm{pH} 4, \mathrm{pH} 7$ and $\mathrm{pH}$ 8. Electricity generation evaluations include electrochemical analysis on the effects of anode $\mathrm{pH}$ microenvironment and polarization behavior.

\subsubsection{Electrochemical analysis on effects of anode $\mathrm{pH}$ microenvironment}

The recorded data from section 2.3 was evaluated. Graph according to anode $\mathrm{pH}$ microenvironments of current versus time and power versus time were plotted and discussed respectively.

\subsubsection{Electrochemical analysis on polarization behavior}

The performance of MFC was investigated based on voltage output of fuel cell after a steady state. The steady state occurs when the voltage reading become stable after operation. The voltage and current were measured using a digital multimeter and was monitored daily for a period of 12 days. Voltage and current were converted to power according to Equation (I).

$$
\mathrm{P}=i \mathrm{~V}
$$

where $\mathrm{P}$ is power in Watt (W), $i$ is current in Ampere (A) and $\mathrm{v}$ is voltage in Volt (V). Power density and current density were calculated using the normalized surface area of the anode electrode. Power curves were derived from the polar curves [11]. Power curves indicated the maximum power density produced from the MFC systems. Polarization curves were formed by varying the external resistance from $100 \Omega$ to $100 \mathrm{k} \Omega$ in parallel circuit connection and were plotted as current density against voltage output. Internal resistances of the MFC systems were determined using the slope of linear regression line of the polar curves [12].

\subsection{Wastewater analysis}

Wastewater parameters were determined using standard method APHA et al. [13]. The POME samples were extracted on day 1 and 12 to determine the efficiency of wastewater treatment in anode chamber. COD was determined. Samples were analyzed in triplicates until standard deviation less than $5 \%$ was achieved.

\section{Results and discussion}

\subsection{Electrochemical analysis}

\subsubsection{Effects of $\mathrm{pH}$ on electricity generation}

The performance of two-chambered MFC in electricity generation was influenced by the variation of anode $\mathrm{pH}$ microenvironments. Figure 1 shows current production utilizing POME as anode substrate at different anode $\mathrm{pH}$ microenvironments. In addition, Table 1 shows the MFC's performance at different anode $\mathrm{pH}$ microenvironments. Generally, significant variation in current production and electrogenic activity over time was observed from the output trend. The trend can be divided into three phases, namely, ascending phase, stationary phase and declining phase. This observation is consistent with Min et al. [14] and Kaewkannetra et al. [15]. 


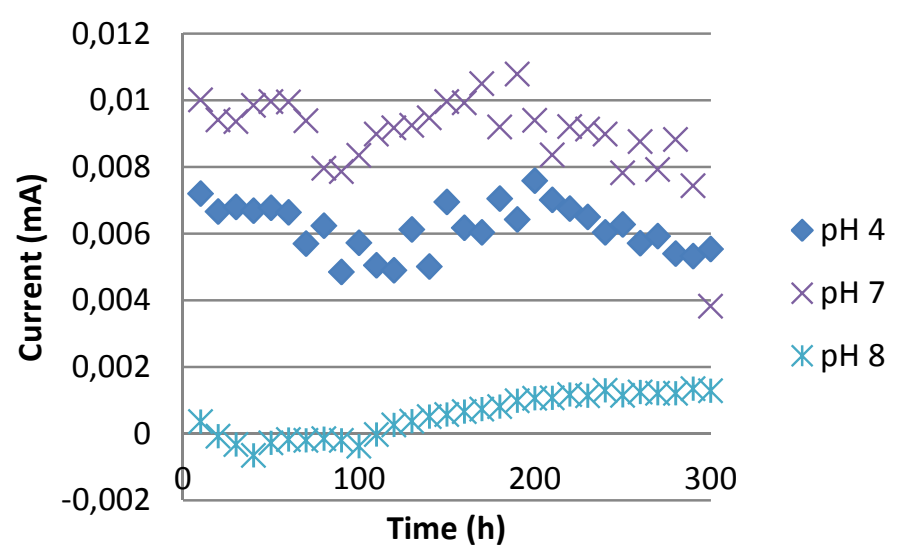

Figure 1: Current production from MFC reactor at different anode $\mathrm{pH}$ microenvironments

Table 1: MFC performance at different anode $\mathrm{pH}$ microenvironments

\begin{tabular}{cccc}
\hline Performance & $\begin{array}{c}\text { Acidophilic } \\
{[\mathrm{pH} 4]}\end{array}$ & $\begin{array}{c}\text { Neutral } \\
{[\mathrm{pH} 7]}\end{array}$ & $\begin{array}{c}\text { Alkaline } \\
{[\mathrm{pH} \mathrm{8}]}\end{array}$ \\
\hline Maximum voltage [mV] & 25 & 35.6 & 4.31 \\
Maximum power [mW] & 0.19 & 0.38 & 0.006 \\
Maximum current [mA] & 0.007 & 0.01 & 0.001 \\
\hline
\end{tabular}

Significant variations in current production and electrogenic activity over time were observed from the output trends shown in Figure 1. The anode with microenvironment $\mathrm{pH} 7$ recorded the optimum anode $\mathrm{pH}$ microenvironment in a two-chambered MFC. At anode $\mathrm{pH} 7$, the voltage of $31 \mathrm{mV}$ was observed during the initial phase of operation. A steady increase in voltage output was observed and finally approached a maximum of $35.6 \mathrm{mV}$ at $190 \mathrm{~h}$. In addition, maximum current of $0.01 \mathrm{~mA}$ at $3.3 \mathrm{k} \Omega$ external resistance was observed. At the optimum anode microenvironment $\mathrm{pH}$ of 7 , the electrogenic bacterial growth is favorable which promotes the growth of microorganisms for electricity generation and contributed to the effective extracellular electron transfer at this anode $\mathrm{pH}$ microenvironment [16]. Neutral anode at $\mathrm{pH} 7$ microenvironment generated higher power compared to acidic and alkaline conditions. This is closely related with the active degradation carried out by the bacteria and internal resistance of MFC system.

At acidic anode $\mathrm{pH}$ of $\mathrm{pH} \mathrm{4}$, the voltage of $22 \mathrm{mV}$ was observed and later approached maximum of $25 \mathrm{mV}$ at $200 \mathrm{~h}$. In addition, maximum current and maximum power was $0.007 \mathrm{~mA}$ and $0.19 \mathrm{~mW}$ at $3.3 \mathrm{k} \Omega$ external resistance respectively. At anode $\mathrm{pH}$ of 4 , it promoted the growth of acidogenic bacteria. The metabolic activity of acidogenic bacteria caused accumulation of methanol as by-product hence decreased the performance. This created a conductive environment for acidogenic bacteria which had a lower $\mathrm{pH}$ around $\mathrm{pH}$ 6. This findings is supported by Mohan et al. [17] and Ishii et al. [18].

Alkaline condition at $\mathrm{pH} 8$ recorded slow increased in both current and power generation and reached its maximum of $0.006 \mathrm{~mA}$ and $0.01 \mathrm{~mW}$ at external resistance $3.3 \mathrm{k} \Omega$. The slow increase production of current and power was due to low activity of the microorganism in POME under alkaline condition and thus resulting in low current and power generation.

In this study, anode microenvironment of $\mathrm{pH} 4$ and $\mathrm{pH} 7$ involved all three phases. However, at pH 8 only two phases was observed, namely, ascending phase and stationary phase. This was due to the low electrogenic activity as the microenvironment was not favorable for microorganisms. A sudden rise in current of $0.01 \mathrm{~mA}$ and $0.007 \mathrm{~mA}$ and power of $0.33 \mathrm{~mW}$ and $0.15 \mathrm{~mW}$ were observed at anode $\mathrm{pH} 7$ and $\mathrm{pH} 4$ respectively. These immediate fluctuations might be due to the difference potential between the two electrodes. In addition, declining phase were to be expected as the organic matter in POME and DWW samples were not replaced in a batch mode experiment and thus became the limiting factor that caused current and power reduction. It was observed that the ascending sequence performance was at $\mathrm{pH} \mathrm{8,} \mathrm{followed} \mathrm{by} \mathrm{pH} 4$ and reached the best performance at $\mathrm{pH}$ 7. A consistence increase in MFC performance was observed might be attributed to the adaptation tendency to the anode $\mathrm{pH}$ microenvironments. 
Generally, in the anode chamber, microorganisms activities of both proton generation and consumption occur at the same time, but a balance need to be established between proton generation and consumption. This can be achieved by controlling the $\mathrm{pH}$ of substrate used. The neutral anode microenvironment of $\mathrm{pH} 7$ showed the highest performance in power and current. This was also reported by Jadhav and Ghangrekar [19] where the amount of proton produced in the anode chamber should penetrate through cation exchange membrane (CEM) and consumed at cathode at the same rate for cathodic reaction. However, this condition did not occur at $\mathrm{pH} 4$ and $\mathrm{pH} 8$ anode microenvironment. Low values of current, power, power density and current density at $\mathrm{pH} 4$ and $\mathrm{pH}$ 8 in the anode microenvironment may be due to slow production rate of proton and electron in the anode chamber and poor proton transfer across CEM which at this $\mathrm{pH}$ is favorable for methanogenesis.

Some differences and similarities were found when comparison was made against previous studies. Behera et al. [20] reported that power generation decreased with decreased in influent $\mathrm{pH}$. However, this study observed an optimum output at anode $\mathrm{pH}$ neutral of $\mathrm{pH} 7$ followed by acidic of $\mathrm{pH} 4$ and later alkaline of $\mathrm{pH}$ 8. Behera et al. [20] and Behera and Ghangrekar [21] reported an optimum anode $\mathrm{pH}$ at $\mathrm{pH} 8$ where the MFC reactor generated $304 \mathrm{mV}$ and $680 \mathrm{mV}$ respectively. These showed a big difference of 71 to 157 times the output of present study. This high result is closely related to MFC setup and materials, namely, single chamber and platinum [21] and dualchamber and Nafion 117 [20]. Besides the studies discussed, other researcher have also found that at acidic condition can also resulted as an optimum condition for maximum output compare to neutral and alkaline condition[3,22]. Raghavulu et al. [3] and Raghavulu et al. [22] observed maximum voltage of $324 \mathrm{mV}$ and $632 \mathrm{mV}$ and maximum current of $1.6 \mathrm{~mA}$ and $5.18 \mathrm{~mA}$ as the metabolic activity of acidogenic bacteria reacts well in this condition. On the other hand, there are other studies agreements on the optimum $\mathrm{pH}$ at neutral $\mathrm{pH}$ of 7 . This condition is suitable for electrogenic bacterial growth and assist in the electron production in anode chamber [23,21]. Therefore, selection on appropriate anode $\mathrm{pH}$ microenvironment is important which triggers the biological pathway and electron production phenomena in the MFC reactor.

\subsubsection{Polarization behavior}

Polarization behavior of MFC during operation was recorded at various external resistances $(100 \Omega-100 \mathrm{k} \Omega)$ to study the electron discharge at various anode $\mathrm{pH}$ microenvironments. Polar curves helps to determine the fuel cell behavior at various external resistances. Figure 2 shows a polar curve at various anode $\mathrm{pH}$ microenvironments while Table 2 shows the performance at different anode $\mathrm{pH}$ microenvironments of MFC reactor. It was observed that voltage generation decreased with increased in resistance which indicated a typical fuel cell behavior. A consistent decreased in current also was observed with increased in resistance. Increased in resistance caused reduction in electron discharge while low resistance increased electron discharge and thus resulting high voltage reading at all different anode $\mathrm{pH}$.

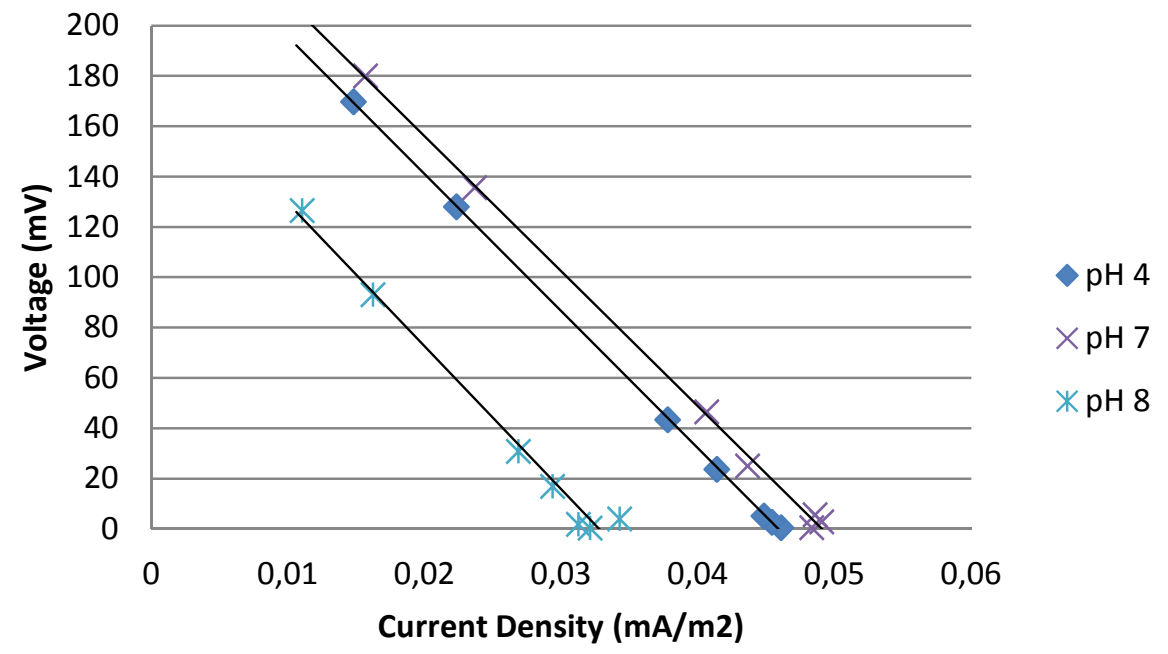

Figure 2: Polar curve at various anode $\mathrm{pH}$ microenvironments 
Table 2: MFC highlighted performance at different anode $\mathrm{pH}$ microenvironments

\begin{tabular}{lccc}
\hline Performance & $\begin{array}{c}\text { Acidic } \\
(\mathrm{pH} 4)\end{array}$ & $\begin{array}{c}\text { Neutral } \\
(\mathrm{pH} \mathrm{7})\end{array}$ & $\begin{array}{c}\text { Alkaline } \\
(\mathrm{pH} \mathrm{8})\end{array}$ \\
\hline Maximum power density $\left(\mathrm{mW} / \mathrm{m}^{2}\right)$ & 2.86 & 3.21 & 1.15 \\
Maximum current density $\left(\mathrm{mA} / \mathrm{m}^{2}\right)$ & 0.046 & 0.049 & 0.034 \\
Internal resistance $(\mathrm{k} \Omega)$ & 5.5 & 5.3 & 6.1 \\
\hline
\end{tabular}

Maximum power density showed highest electron discharge and also indicated the low internal resistance of the MFC system when power density is at its maximum performance. The observed maximum power density at acidic, neutral and alkaline were $2.86 \mathrm{~mW} / \mathrm{m}^{2}$ at $5.5 \mathrm{k} \Omega, 3.21$ $\mathrm{mW} / \mathrm{m}^{2}$ at $5.3 \mathrm{k} \Omega$ and $1.15 \mathrm{~mW} / \mathrm{m}^{2}$ at $6.1 \mathrm{k} \Omega$ respectively. Alkaline and acidic condition showed maximum power density at comparatively low performance as the internal resistance at alkaline and acidic condition was very high $(5.5-6.1 \mathrm{k} \Omega)$. Meanwhile, the maximum power density had low internal resistance of $5.3 \mathrm{k} \Omega$ which generated more power due to enhance in higher electron discharge. This enumerates the feasibility of neutral condition in effectively discharging the electrons compared to acidic conditions. In addition, at lower resistance condition, the electrons move more easily through the circuit compared to at higher resistance. Higher oxidation reaction by the microbes is expected at a lower resistance and therefore the MFC can be operated at lower resistance to remove the organic matter at a higher rate (Jang et al., 2004). It was observed that a rapid voltage drop at lower external resistance and voltage was getting stabilized at higher external resistance. The rapid voltage drop and slow stabilization of voltage were due to the rate of electron discharge at lower resistance.

In comparison with other anode $\mathrm{pH}$ microenvironment, acidic condition showed a stable voltage output until $300 \mathrm{~h}$. This suggested that the operation of MFC must be controlled consistently at optimum anode $\mathrm{pH} 7$ throughout the experiment. Appropriate selection of anode $\mathrm{pH}$ microenvironment will support the continuous electron discharge from substrate degradation [22] as the anode chamber controls the kinetics of $\mathrm{e}^{-}$transfer from microorganism to the anode [22].

Raghavulu et al. [3] and Raghavulu et al. [22] reported that the optimum $\mathrm{pH}$ was slightly acidic condition of $\mathrm{pH} 6$ using chemical wastewater as substrate. A power density of $12.72 \mathrm{~mW} / \mathrm{m}^{2}$ and $62.7 \mathrm{~mW} / \mathrm{m}^{2}$ were reported using single chamber and two-chamber respectively [3,22]. The high power density observed was due different setups. Studies carried out by Ghangrekar with fellow researcher, found that two-chambered MFC can produces as high as $600 \mathrm{~mW} / \mathrm{m}^{2}$ at alkaline $\mathrm{pH}$ of $\mathrm{pH} 8$ however this was due the suspension sludge concentration and substrate were oxidized by other anaerobic microorganism in the anode chamber [20,21]. Nevertheless, this study is in-line with Jadhav and Ghangrekar [19] which reported that the $\mathrm{pH}$ near neutral is the optimum $\mathrm{pH}$ in the anode chamber. Jadhav and Ghangrekar [19] observed a power density of $17.1 \mathrm{~mW} / \mathrm{m}^{2}$ and 15.2 $\mathrm{mW} / \mathrm{m}^{2}$ with internal resistance of $523 \Omega$ and $547 \Omega$ at anode $\mathrm{pH}$ of 6.5 and 7 respectively. This was due the $\mathrm{pH}$ condition near neutral was ideal for the bacteria activities to oxidize and reduce proton and electron in both chambers hence high output with low internal resistance was observed.

\subsection{Wastewater treatment}

Besides power generation, wastewater treatment in the anode chamber was also observed during MFC operation. The COD reduction obtained were $65 \%, 55 \%$ and $43 \%$ at acidic, neutral and alkaline anode $\mathrm{pH}$ condition respectively. In contrary to the power generation, acidic anode $\mathrm{pH}$ 4 microenvironment showed highest percentage COD removal followed by neutral microenvironment at anode $\mathrm{pH} 7$ and finally alkaline at anode $\mathrm{pH}$ 8. The experimental results clearly demonstrated that the MFC performance is dependent on the anode $\mathrm{pH}$ microenvironments. The increase of COD removal efficiency was observed when $\mathrm{pH}$ of anode microenvironment decreased. This is attributed to the shorter acclimatization period of the anaerobic bacteria inside the MFC as acidic condition represents the natural POME environment at the initial stage of MFC operation.

Besides, acidic microenvironment in anode chamber may be attributed to the efficiency of methanogenic bacteria in metabolizing the substrates [22] and supported the growth of 
methanogenic bacteria and other non-specific microbial populations. Moreover, acidic condition generally enhance the function of methanogenic bacteria and creates conductive environment for the proliferation of acidogenic bacteria, where complete reduction of substrate was feasible [22]. Methanogenic bacteria functioned effectively in near $\mathrm{pH} 7$ while acidogenic bacteria had lower $\mathrm{pH}$ optimum around $\mathrm{pH} 6$ and were insensitive to acidic conditions [24].

Previous studies on increase of anode $\mathrm{pH}$ reported an improved in percentage of removal COD ranged $55.76 \%-85.4 \%, 58.98 \%-88.5 \%, 47.8-92.6 \%$ at $\mathrm{pH} 6,7$ and 8 respectively $[3,20,22]$ The improved COD removal was due to adaptation of bacteria to the initial condition which is electrochemically active and later favors the condition near neutral which promote bacterial growth [19].

\subsection{POME as substrate}

The high levels of COD and conductivity of POME encourage the electricity generation. The importance of high conductivity for maximizing electricity generation has been highlighted by Huang and Logan [25]. They reported that an increased in the power density of $245 \%$ when the solution conductivity was raised from $0.8 \mu \mathrm{S} / \mathrm{cm}$ to $10.2 \mu \mathrm{S} / \mathrm{cm}$. As the conductivity of solution increased, the internal resistance for power generation in the system became lower and facilitated the transport of ions through the anode biofilm [21]. This condition might be due to the presence of electrochemically active microorganisms. The solution conductivity of POME sample used in this study was about $9.36 \mu \mathrm{S} / \mathrm{cm}$ which was considered conductive. Therefore, the POME sample is a highly potential candidate for MFC substrate for electricity generation as it is conducive and is readily biodegradable waste with high COD.

POME samples used in this study was acidic in nature and neutralization of the wastewater is necessary for biological treatment and to promote growth of bacteria in the wastewater. Higher acidity or alkalinity of wastewater affects both wastewater treatment efficiency and the microenvironment of the reactor. The neutral $\mathrm{pH}$ condition needs to be maintained in order to achieve favorable biological treatment condition for microorganism growth and metabolic activities hence maximizes electricity generation.

\section{Conclusions}

This study demonstrated electricity generation and effective wastewater treatment utilizing POME as substrate in a two-chambered MFC reactor. This study revealed that the performance of MFC was found to be dependent on the anode $\mathrm{pH}$ microenvironments. It was demonstrated that anode $\mathrm{pH}$ microenvironments affects the anodic bacterial activity and the overall performance of the MFC. From the experiments it was found that the bacteria in POME can tolerate anode $\mathrm{pH}$ at acidic as low as $\mathrm{pH} 4$ and at alkaline $\mathrm{pH}$ as high as $\mathrm{pH}$. The optimum condition at neutral $\mathrm{pH} 7$ anode microenvironment was observed with the performance on electricity generation of $35.6 \mathrm{mV}$, $0.38 \mathrm{~mW}$ and $0.01 \mathrm{~mA}$. This condition was favorable for higher power generation and high treatment efficiency compared to acidic and alkaline microenvironment conditions. In addition, 55 $\%$ COD removal efficiency at $\mathrm{pH} 7$ produce maximum current. The COD removal efficiency indicated the functioning of MFC as an alternative wastewater treatment in addition to renewable energy generation.

\section{Acknowledgement}

The grant provided by Universiti Teknologi MARA, Malaysia (600-RMI/ST/DANA 5/3/Dst (498/2011)) is duly acknowledged. 


\section{References}

[1] R.M. Allen, H.P. Bennetto, Microbial fuel cells: Electricity production from carbohydrates, Appl. Biochem. Biotechnol. (1993) 27-40.

[2] J.R. Kim, S.H. Jung, J.M. Regan, B. Logan, Electricity generation and microbial community analysis of alcohol powered microbial fuel cells. Bioresour. Technol. 98 (2007) 2568-2577.

[3] S.V. Raghavulu, S.V. Mohan, Venkateswar, M.M. Ghangrekar, P.N. Sarma, Behavior of single chambered mediatorless microbial fuel cell (MFC) at acidophilic, neutral and alkaline microenvironments during chemical wastewater treatment, International Journal of Hydrogen Energy. 34(17) (2009) 7547-7554.

[4] B.E. Logan, B. Hamelers, R.A. Rozendal, U. Schroder, J. Keller, S. Freguia, P. Aelterman, W. Verstraete, K. Rabaey, Microbial fuel cells: Methodology and technology, Environ. Sci. Technol. 40 (2006) 5181-5192.

[5] S.A. Patil, V. Prasad, S. Koul, S. Ijmulwar, A. Vivek, Y.S. Shouche, B.P. Kapadnis, Electricity generation using chocolate industry wastewater and its treatment in activated sludge based microbial fuel cell and analysis of developed microbial community in the anode chamber. Bioresource Technology. 100(21) (2009) 5132-5139.

[6] Y. Zuo, S. Cheng, B.E. Logan, Ion exchange membrane cathodes for scalable microbial fuel cells, Environ. Sci. Technol. 42 (2008) 6967-6972.

[7] S. Sumathi, S.P. Chai, A.R Mohamed, Utilization of oil palm as a source of renewable energy in Malaysia, Renewable and Sustainable Energy Reviews. 12(9) (2008) 2404-2421.

[8] S.C. Chua, T.H. Oh, Review on Malaysia's national energy developments: Key policies, agencies, programmes and international involvements, Renewable and Sustainable Energy Reviews. 14(9) (2010) 2916-2925.

[9] G.D. Najafpour, M. Rahimnejad, N. Mokhtarian, W.R. Wan-Daud, A.A. Ghoreyshi, Bioconversion of whey to electrical energy in a biofuel cell using Saccharomyces cerevisiae, World Applied Sciences Journal. 8 (2010) 01-05.

[10] Z. Du, H. Li, T. Gu, A state of the art review on microbial fuel cells: A promising technology for wastewater treatment and bioenergy, Biotech. Adv. 25 (2007) 464-482.

[11] W. Verstraete, K. Rabaey, Critical Review Microbial Fuel Cells: Methodology and Technology. Environ. Sci. \& Technol. 40(17) (2006) 5181-5192.

[12] C. Picioreanu, I.M. Head, K.P. Katuri, M.C.M. van Loosdrecht, K.Scott, A computational model for biofilm-based microbial fuel cells, Water Research. 41(13) (2007) 2921-2940.

[13] APHA, Standard Methods for Examination of Water and Wastewater, 22th ed. American Public Health Association, American Water Works Association, Water Pollution Control Federation, Washington, DC, 2012.

[14] B. Min, J. Kim, S. Oh, J.M. Regan, B.E. Logan, Electricity generation from swine wastewater using microbial fuel cells, Water Research. 39(20) (2005) 4961-4968.

[15] P. Kaewkannetra, W. Chiwes, T.Y. Chiu, Treatment of cassava mill wastewater and production of electricity through microbial fuel cell technology, Fuel. 90(8) (2011) 2746-2750. [16] M. Behera, M.M. Ghangrekar, Performance of microbial fuel cell in response to change in sludge loading rate at different anodic feed pH, Bioresource Technology. 100(21) (2009) 5114 5121.

[17] S.V. Mohan, V.Y. Bhaskar, P.N. Sarma, Biohydrogen production from chemical wastewater treatment in biofilm configured reactor operated in periodic discontinuous batch mode by selectively enriched anaerobic mixed consortia, Water Res. 41 (2007) 2652-2664. 
[18] S. Ishii, Y. Hotta, K. Watanabe, Methanogenesis versus electrogenesis: Morphological and Phylogenetic comparisons of microbial communities, Biosci. Biotechnol. Biochem. 72(2) (2008) 286-294.

[19] G.S. Jadhav, M.M. Ghangrekar, Performance of microbial fuel cell subjected o variation in $\mathrm{pH}$, temperature, external load and substrate concentration, Bioresource Technology. 100(2) (2009) 717-723.

[20] M. Behera, P.S. Jana, T.T. More, M.M. Ghangrekar, Rice mill wastewater treatment in microbial fuel cells fabricated using proton exchange membrane and earthen pot at different $\mathrm{pH}$, Bioelectrochemistry. 79(2) (2010) 228-233.

[21] S.V. Raghavulu, S.V. Mohan, R.K. Goud, P.N. Sarma, Effect of anodic pH microenvironment on microbial fuel cell (MFC) performance in concurrence with aerated and ferricyanide catholytes, Electrochemistry Communications. 11(2) (2009) 371-375.

[22] Z. He, Y. Huang, A.K. Manohar, F. Mansfeld, Effect of electrolyte pH on the rate of the anodic and cathodic reactions in an air-cathode microbial fuel cell, Bioelectrochemistry. 74(1), (2008) 78-82.

[23] Y. Mohan, S.M. Muthu Kumar, D. Das, Electricity generation using microbial fuel cells, Int. J. Hydrogen Energy. 33 (2008) 423-426.

[24] L. Huang, B.E. Logan, Electricity generation and treatment of paper recycling wastewater using a microbial fuel cell, Applied Microbiology and Biotechnology, 80(2) (2008) 349-355. 